\title{
Vocational Education, Transitions, Marginalisation and Social Justice in the Nordic Countries - Reflections on the Special Issue
}

\begin{abstract}
This paper engages with and reflects on the arguments developed by contributors to the special issue. These papers serve to provide a corrective to English, and on occasion, European perceptions which often view the Nordic countries as being all of a piece and beacons of progressivism. The contributors provide analyses that not only point to the impact of neo-liberalism upon vocational education and training (VET) but also the different ways in which it is delivered across the Nordic countries. They alert us to VET's complexity and varied forms. Nevertheless, it appears there are a set of repertoires that can be mobilised to address the relationship between VET and youth transitions to work and vocational study which seem to circulate across time and place. The circulation of these models suggests they fail to address the deeper issues facing VET, namely the relation of VET in particular and 'academic' education in general to capitalism, and importantly, the salience of these processes in the current conjuncture. These relations raise questions about the reproduction of class relations and the specificity of the socio-economic contexts. This leads to a consideration of notions of social justice and an interrogation of VET with this particular question in mind. An important issue that needs to be explored is the way in which the curriculum opens-up or closes-down access to powerful knowledge. Whilst education in Bernstein's words "cannot compensate for society", can it nevertheless be a resource in the transformative struggle for a just society?
\end{abstract}




\section{Vocational Education, Transitions, Marginalisation and Social Justice in the Nordic Countries - Reflections on the Special Issue}

Introduction

In this commentary on the papers in the special issue I raise a number of key points. To that end I consider the manner in which the papers address Nordic welfare regimes, the different approaches that the Nordic countries have applied to vocational education and training (VET) as well as the policy repertoires that are applied to this sector. In addition, these papers explore the manner in which we conceive the relationship between VET and 'academic' education. All the papers are located within a broader concern with the impact of neo-liberalism on VET. Running throughout this commentary is an interest in questions of social justice, the socio-economic context, the re-composition of class relation as well as the way in which we think about academic and vocational knowledge.

\section{Reflections on the papers}

In this section I address themes concerned with, Nordic welfare regimes, the specificity of VET and academic education and its relation to capital. Not only for many English readers but also for some European readers the notion of the Nordic welfare state conjures up a number of stereotypes. It is often viewed as a beacon of progressivism set within social democracy, characterised by comprehensive education systems and a wider social formation marked by a relatively narrow distribution of income and wealth (EspingAndersen, 1990; Walther, 2006). Bathmaker (2017) has described the Nordic regime as a universal model of welfare capitalism that aims to eliminate market-generated inequalities through the generous provision of welfare services. Jørgensen $(2017,2018)$ suggests there are a number of distinctive features of the Nordic education model;

- Common egalitarian values and policy goals

- Linked to the universal model of welfare state

- Free, public provision of education for all

- The non-selective, comprehensive school (2017, slide 2)

Importantly, the papers in this special issue offer a corrective to the view that there is a particular and universal model of Nordic welfare regimes. The papers accomplish this in two key ways. Firstly, they offer a nuanced account of VET and youth transition policies in the Nordic countries. Secondly, they overcome the problems with ahistorical analyses through their recognition of the impact of neoliberalism on welfare regimes.

In what follows I make a number of observations and reflections generated by the five papers in this special issue.

(i) A Nordic transition regime? Policies for school-to-work transitions in Sweden, Denmark and Finland. (Jørgensen, Järvinen \& Lundahl, 2019) 
(ii) A tale of two reforms: Institutional change in vocational education and training in Norway and Sweden in the 1990s. (Persson Thunqvist, Hagen Tønder \& Reegård, 2019)

(iii) Balancing 'flexibility' and 'employability': The changing role of general studies in the Finnish and Swedish VET curricula of the 1990s and 2010s. (Nylund \& Virolainen, 2019)

(iv) Imagining societies through discourses on educational equality: A cross-cultural analysis of Finnish and Swedish upper secondary curricula from 1970 to the 2010s. (Lappalainen, Nylund \& Rosvall, 2019)

(v) VET teachers' interpretations of individualisation and teaching of skills and social order in two Nordic countries. (Eiríksdóttir \& Rosvall, 2019)

The papers complement one another well and their strength lies in that they spell out the specificity of policy and practice in the Nordic countries of Sweden, Finland, Denmark, Norway and Iceland. Importantly, they examine the relationship between the academic and vocational in relation to pedagogic and curriculum practices. With respect to school-towork transitions the papers by Jørgensen, Järvinen, and Lundahl, and that by Persson Thunqvist, Tønder and Reegård serve as correctives to the notion of a Nordic universalistic transition regime. As against the earlier analyses of Walther (2006) they offer a more nuanced account that points towards the tension that Jørgensen $(2018,1)$ has described as "a trade-off between social inclusion and social equality". Jørgensen et al discuss the manner in which certain groups of young people come to be defined as 'vulnerable' or at risk. The consequence is that whilst policy may seek to address the social inclusion of such young people it simultaneously constructs them as the other and may in this way reproduce inequality.

At the same time the papers in the special issue alert us to the different and "messy" approaches to VET in the Nordic nations. They illustrate the historical twists and turns in the provision of VET and academic education, and by implication, the varying coalitions that have formed around education and training as well as youth transitions. This can be seen in the papers by Persson Thunqvist, Tønder and Reegård, and Nylund and Virolainen , which suggests to me that there are a set of policy repertoires that can be called upon to address the relationship between VET and academic (general) education. Thus, a particular coalition of interests may be committed to particular policies etc., in relation to youth transition, VET and so on. Persson, Thunqvist, Tønder and Reegård's paper addresses such issues and encourages us to think about not only continuity and change but also power and contradiction.

Whilst there are a number of policy repertoires surrounding the relationship between VET and academic education it seems to me that these fail to address the deeper problems facing VET - hence the twists and turns in policy interventions. Interestingly, in the papers themselves, little was said about the relation of VET and academic (general) education to capital. If this had been more fully addressed in the papers it could have offered a way of explaining the twist and turns that policy interventions have taken. However, it might be that the relation of VET and academic education to capital is seen as so self-evident that it is unremarkable and taken for granted, unless that is, neoliberalism is seen as a gloss for 
capital. If this is the case, and neoliberalism is understood in this way, this raises questions about the manner in which we understand social democratic welfare regimes, or as I prefer to call them, settlements (Avis, 2017; Education Group, 1981; Education Group II, 1991). The latter term implies that such settlements are always tenuous, open to contestations and have to be constantly re-secured. Such an approach would alert us to the twist and turns of policy making as well as their national specificity.

Whilst there may be something of an affinity between the above discussion and the work of Thelen and Busemeyer (2011, and see Busemeyer, 2015), there is a tension. It seems to me that analyses that draw on and emphasise the institutional context and salience of partisan politics underplays the significance of capitalism and its accumulation strategies. This points towards questions that are located within a systematic analysis of capitalist relations. Such an analysis would address a number of issues amongst which we could include the class basis of academic/vocational divisions, the esteem attributed to these and the manner in which this is played out alongside the reproduction of the mental/manual divide. However, such issues need to be set alongside a changing occupational structure and labour market, that is increasingly characterized by precarious employment and the hollowing out of middle level occupations.

All of these issues can and need to be strongly related to notions of class struggle, contradiction and the systemic features of capital as well as recognising capitalism as a dynamic system. Clearly all of this is messy and complex, but the key question becomes how far can we push capitalism in progressive directions in relation to VET and social justice. At the start of this paper I commented on English perceptions of the progressive Nordic welfare state. The papers in this special issue alert us to the impact of neo-liberalism upon Nordic welfarism and the way in which this has been undermined in recent years. The question is then posed as to whether an egalitarian capitalism is feasible, one that could align with a VET committed to social justice - or is such an aspiration a contradiction in terms (Kenworthy, 2004)? The latter suggests, as does recent history, that capital will always seek to claw back the concessions it made in earlier periods - such as the social democratic settlement following the second world war.

On a slightly different tack the paper by Eiríksdóttir and Rosvall draw our attention to the presence of high ability students following VET courses. This offers an important corrective to the stereotype of VET being associated with low level courses and for 'other people's children'. The point is, if we need to acknowledge that some high ability students do pursue VET, ironically this serves to illustrate its low esteem and by default its status problem. It may also point to the different ways in which VET articulates to particular classed constituencies and changing labour market conditions.

As mentioned earlier the papers complement one another and in the process of reading them I found myself thinking about ethnographic data - the type of data that points towards the lived experience of teacher, student and stakeholder. However, much of the discussion in the papers concerns the prescribed curriculum as against the lived experiences of learners engaging with the enacted curriculum - or what could be described as the curriculum in practice. A fuller engagement with the lived experiences of learners and 
teachers with the enacted curriculum could have pointed towards spaces in which progressive practices arose as well as those that served to challenge neoliberalism.

It would be useful to say something about the curriculum and discussions that set the vocational against the academic. I think there is a tension in this debate but this may be to do with my reading of the papers - my discursive positioning if you like. It seems to me that the academic is construed as the site of critique - much is made of 'source criticism' and so on - the implication being that this is a pivotal feature of the academic curriculum that can be mobilised in critiques of the status quo. However, such an attribution to the academic may well be overstated and play down the critical possibilities that are present in the vocational curriculum. This is why it is important for analyses to move from the level of policy formation and the prescribed curriculum to its enactment and the lived experiences of teachers and students. I would like to make three points. Firstly, there is a resonance with Bowles and Gintis' (1976) correspondence theory which concerns the reproduction of middle and working class relations and the mental/manual divide. Even the terms academic and vocational are class loaded. Secondly, as the authors in this special issues are well aware, the academic is not all of a piece with disciplines such as sociology having horizontal knowledge structures as against the vertical structures of the natural sciences (Bernstein, 2000). Thirdly, but perhaps most importantly, the curriculum is a site of struggle located within a move towards genericism and the regionalisation of knowledge whereby education becomes orientated towards a particular field of practice, as has been the case with VET. Conceptualisations of genericism and regionalisation are closely related. Beck and Young $(2005,189,190)$ in their discussion of these notions point towards the development of particular regions or fields of practice such as business studies, tourism and so on, which draw on a range subject disciplines. This has been a longstanding feature of VET.

Genericism points towards a new knowledge structure that is directly concerned with the needs of employers and selects curriculum content on this basis, with soft skills, flexibility and interdisciplinarity being stressed. Importantly, not dissimilar processes can be seen in the academic curriculum, whereby moves towards genericism is reflected in the importance attached to soft skills and the salience of CV building, which in turn is allied to concerns with relevance and instrumentalism.

It was useful to encounter ethnographic data in Eiríksdóttir, Rosvall's paper and it is important to consider the lived experiences of students following both academic and vocational curricula, not only in terms of genericism but also with respect to the curriculum in practice. By addressing the lived experience of learners one could explore whether the academic is experienced as empowering. More extensive use of ethnographic accounts in the papers would have been useful in exploring these issues and in the case of the academic could have moved debate beyond the potentiality of 'source criticism' to its enactment. A not dissimilar point could be made in relation to the development of VET curriculum and policy. This could also have been allied to a more fulsome engagement with stakeholders, such as policy makers, employers and the various interest that surround the development of education policy and curriculum and would have added to the 'richness' of the papers. 
Whilst there is some reference in the papers to employers, stakeholders and their organisations this could have been pushed further and serves to raise a number of question - who speaks for whom, whose voice is heard and where does agency lie? Importantly, this points towards a consideration of the discursive positioning of employers and state rhetoric - its hegemonic or doxic stance. Not only do such issues raise questions about agency but also about who benefits from the way in which VET and academic education is configured in the current conjuncture? And, how does this relate to the broader socio-economic context?

All the papers mention the impact of neo-liberalism upon education, VET and wider society and point towards a nuanced analysis that takes into account the specificity of different societies/social formations. Whilst competitiveness, marketization and the commodification of education can readily be ascribed to neoliberalism, nevertheless it is important to remember it is not all of a piece (Jessop, 2015). We need to acknowledge the manner in which the neo-liberal project served to unpick the class alliances and interests that secured the social democratic welfare regime.

There are several points I would like to make. Firstly, social democratic regimes are marked by their specific histories and the particular class constituencies that coalesced in their formation. Esping-Anderson (1990) has commented on this with respect to Sweden and the "red green" coalition, an alliance between socialists and rural constituencies. He has also discussed the role of the Christian Democrats in the formation of German corporatism, as has Busemeyer (2015). Secondly, following Gramsci and the Centre for Contemporary Cultural Studies (Education Group, 1981; Education Group II, 1991), I have found the notion of settlement helpful - the social democratic settlement and the notion that settlements have to be continually secured and are always vulnerable to contestation. Thirdly, to the extent that there is a neo-liberal settlement, it is one that is heavily contested. How then do we make sense of the move towards neo-liberalism? Should we view this, as Michael Apple (2013) does, as the restoration of class power, or maybe more correctly the reassertion of the interests of capital. It should be noted that capital is not all of a piece but is itself fragmented into various fractions, for example finance, neo-mercantilism and other variegated forms which are partly captured by the notion of the 'varieties of capitalism' (Jessop, 2015; Hall and Soskice, 2001). But regardless of its variety the logic of capital is always one of accumulation and struggle.

The UK experience has something to offer in debates concerning social democracy. I would like to refer to the ideas of Ralph Miliband drawing on two quotes. The first comes from his The State in Capitalist Societies, published 50 years ago (1969)

Social-democratic parties, or rather social-democratic leaders, have long ceased to suggest to anyone but their most credulous followers (and the more stupid among their opponents) that they were concerned in any sense whatever with the business of bringing about a socialist society. (Miliband 1973, 244)

The second is from Class Power and State Power published in 1983, in which he describes 
Labourism: [as] an ideology of social reform, within the framework of capitalism, with no serious ambition of transcending that framework. (Miliband, 1983, 293)

The reason for drawing attention to these quotations is not to construct an ahistorical or essentialist construction of social democracy and labourism but to offer a corrective to analyses that play down the contradictions and tensions that surrounded the social democratic settlement.

It was interesting to note the engagement with Fraser's (2008) notions of social Justice in Lappalainen, Nylund and Rosvall's paper which embodies three dimension. The first, redistribution calls for a fairer distribution of economic resources - a flatter distribution of income and wealth. The second, recognition calls for an acknowledgement and valuing of difference, for example, whether these be in terms of race, gender, sexuality and so on. The third, participatory parity calls for political parity of voice whereby the marginalised can be heard on an equal footing to the privileged and advantaged. For the above authors there is a struggle over recognition and redistribution within curriculum/policy documents. There is a link here to the work of Young and Lambert (2014) as well as Wheelahan (2010). For Wheelahan vocational students need access to forms of disciplinary/ academic knowledge so that they are in a position to evaluate it in relation to their vocational practice. This goes beyond a piece-meal engagement with such knowledge which precludes a broader understanding that would facilitate critique, and for Wheelahan is a question of distributive justice. Such a stance reflects the tension between a concern with social inclusion and social equality. It also touches on the way in which we make sense of disciplinary/academic knowledge. Young and Lambert (2014) distinguish between knowledge of the powerful and powerful knowledge, the latter can be gained through disciplinary knowledge and consequently access becomes a question of social justice.

In an earlier version of their paper Lappalainen, Nylund and Rosvall also make a link with Bernstein's notion of pedagogic rights and learners access to critical knowledge, a process that is compromised not only in vocational but also by the regionalisation of academic education (see also Eiríksdóttir \& Rosvall, 2019). What would be useful is to relate this to Lingard et al's discussion and then comment on broader issues of class. There is an affinity between the preceding discussion of social justice and Lingard, Sellar and Savage's (2014) analysis of Australian education policy in which social justice has been re-articulated away from a concern with equality towards one of equity. This has arisen as a result of the shift away from social democracy to a neo-liberalism wedded to the market. In the former, social democratic understandings of equality were located in a broader engagement with philosophical issues about the nature of social justice within society and its relationship to class inequalities and so on. The notion of equity on the other hand is reductive and calculative, serving to close down philosophical questions and replace these with quantitative data. This to me also raises questions about the re-composition of class relations.

\section{Discussion}


What I want to do here is to close the discussion by raising two questions that bear upon the manner in which we could think about the relationship between VET and academic education and the broader socio-economic context. The first concerns the rhetoric of the knowledge society - that of up-skilling, the skills gap and so forth that bears upon VET and academic education. This rhetoric needs to be placed within a broader socio-economic context that has a number of features amongst which we could include what Brown, Lauder, and Ashton (2011) refer to as digital Taylorism that problematises notions of upskilling and the skills gap. This refers to the process through which formerly skilled jobs have become standardised as a result of digitalization. We could think about home or car insurance which can be purchased online or via a call centre where the operative follows a standardised procedure. Brown, Lauder, and Ashton (2011) point out that as a result of the internet and digitalization work can follow time zones and in effect operate $\mathbf{2 4}$ hours a day, with the resulting consequences for paid labour. The new condition in which labour is placed exacerbates the struggle for positional advantage of class groupings. This follows on from the compression of time and space but is also a result of increased precariousness, under and unemployment and overqualification. As a result, the struggle to secure or improve one's position becomes more acute (Brown, 2016). This is allied to the decline of the European middle class and what some have described as its hollowing out following the restructuring of paid labour and the loss of middle level jobs (VaughanWhitehead, 2016; Streeck, 2014). Consequently, throughout the occupational structure and labour market there are increasing levels of insecurity and precarité. (Standing, 2014). We encounter a dynamic and changing class structure marked by over-education /qualification and under-employment with some middle class youth shuffling down the occupational scale leading to what Piketty $(2014,416)$ refers to as 'meritocratic extremism' characterised by an increasing polarisation between the 'super-rich' and the rest of the society. At the same time social geographers alert us to the blurring between local, regional and global labour markets. Within the same locality high levels of disadvantage and exclusion from work may exist, alongside a global labour market that offers high income and prestige (Martin and Morrison, 2003). The point is that the preceding discussion serves to frame the position of academic and vocational education. These issues at one and the same time reflect the impact of neoliberalism as well as the current conditions in which education is placed.

Secondly, other writers draw our attention to the notion of surplus labour (Marsh, 2011) with Blacker suggesting,

The current neoliberal mutation of capitalism has evolved beyond the days when the wholesale exploitation of labor under-wrote the world system's expansion. While "normal" business profits plummet and theft-by-finance-rises, capitalism now shifts into a mode of elimination that targets most of us - along with our environment - as waste products awaiting managed disposal. (Blacker, 2013, 1)

Such processes sit alongside classed based higher education systems. I am reminded of the English HE system that is highly differentiated and which anticipates different class based routes to employment, under-employment and over-qualification. It is of course important to acknowledge that class relations are not simply that, but are intertwined with those of gender and race, captured in the notion of intersectionality. Whilst many of the authors in 
the special issue acknowledge these interrelations, particularly gender and class, more attention could have been given to race/ethnicity and their articulation with immigrant status. It is the case that little current work, particularly in the UK, addresses the articulation of VET with race and ethnicity (but see Avis, Orr and Warmington 2017; Avis, Mirchandani and Warmington, 2017).

The previous points raise questions about the relation of education in general and VET in particular to the class structure, and its ability to interrupt or reproduce class based inequalities. Perhaps it would be best to give the last word to Bernstein (1970) and Apple (2013). In less austere times Bernstein (1970) argued that 'education cannot compensate for society', but as he and Apple suggest this is not to claim that education cannot be a resource in the struggle for social justice (Apple 2013, and see Avis and Orr, 2016). However, these struggles need to be lodged in a wider politics that is committed to societal transformation, for without such a politics we are doomed at best to mitigate the inequalities present in society rather than their transcendence.

\section{Conclusion}

The papers in this special issue illustrate that there is neither a homogenous Nordic welfare regime nor a common VET response to neoliberalism. Indeed, there appears to be a repertoire of responses that vary overtime and location. The fluidity surrounding these suggest that VET policy fails to address deeper structural issues and contradictions that face society. It is at this juncture that a more fulsome engagement with the relationship between capital, VET and academic education would have been helpful. Such an engagement would lead to an analysis that explored the reproduction of class relations together with their re-formation, allied to a concern with social justice and the curriculum. Such an analysis could lead to an interrogation of VET and academic education and the manner in which they open-up or close-down access to powerful knowledge.

\section{Declaration of conflicting interest}

The author(s) declared no potential conflicts of interest with respect to the research, authorship, and/or publication of this article.

\section{Funding}

This work was supported by NordForsk through the Nordic Centre of Excellence JustEd [grant number 57741], NordVET [grant number: 54782] and the network Vocational education, transitions, marginalisation and social justice [grant number 57741].

\section{References}

Apple, M. 2013. Can Education Change Society. London: Routledge.

Avis, J. 2017. Crossing Boundaries: VET, the Labour Market and Social Justice. Keynote address: Crossing boundaries in Vocational Education and training: social dimensions and participation. Institut Berufspädagogik, Universität Rostock, 16-18 August 2017 
Avis, J., Mirchandani, K., Warmington, P. 2017. Editorial, Journal of Vocational Education \& Training, Special Issue, Vocational Education and training and Race/Ethnicity 69(3) 287-291

Avis, J., Orr, K. 2016. HE in FE: Vocationalism, Class and Social Justice, Research in Postcompulsory Education, 21(1-2) p49-65

Avis, J., Orr, K., Warmington, P. 2017. Race and Vocational Education and Training in England, Journal of Vocational Education \& Training, 69(3) 292-310

Bathmaker, A-M. 2017. Seeking distinction and addressing inequalities: new times for college-based higher education in England, paper presented Journal of Vocational Education and Training, 12th International Conference Worcester College Oxford 7-8 July

Beck, J. and Young, M. (2005) 'The assault on the professions and the restructuring of academic and professional identities: a Bernsteinian analysis', British Journal of Sociology of Education, 26(2) p183-97.

Bernstein, B. 1970. "Education Cannot Compensate for Society." New Society 15: 387

Bernstein, B. 2000. Pedagogy, Symbolic Control, and Identity, Revised Edition, New York, Rowman \& Littlefield Publishers

Blacker, D. 2013. The falling rate of learning and the neoliberal endgame, London, Zero books

Bowles, S., Gintis, H. 1976. Schooling in Capitalist America, London, Routledge

Busemeyer, M.R. 2015. Skills and Inequality, Cambridge, Cambridge University Press

Esping-Andersen, G. 1990. The three worlds of welfare capitalism, Cambridge, Polity

Education Group. 1981. Unpopular Education Schooling and social democracy in England since 1944 London, Hutchinson

Education Group II. 1991. Education Limited: Schooling and training and the New Right since 1979, London, Unwin Hyman

Eiriksdottir, E., \& Rosvall, P.-Å. (2019). VET teachers' interpretations of individualisation and teaching of skills and social order in two Nordic countries. European Educational Research Journal.

Fraser, N. 2008. Scales of justice. Reimagining political space in a globalizing world, Cambridge: Polity Press.

Fraser, N. (2013). Fortunes of Feminism. London: Verso. 
Hall, P. A., Soskice, D. (Eds) 2001. Varieties of Capitalism: The Institutional Foundations of Comparative Advantage, Oxford, Oxford University Press

Jessop, B. 2015. Neoliberalism, finance-dominated accumulation and enduring austerity: a cultural political economy perspective, in Farnsworth, K., Irving, Z. (Eds) Social Policy in tines of Austerity, Bristol, Policy Press

Jørgensen, C., H. 2017. VET in the Nordic countries - a trade-off between social inclusion and social equality? paper presented Journal of Vocational Education and Training, 12th International Conference Worcester College Oxford 7-8 July

Jørgensen, C., H. 2018. Learning from VET in the Nordic countries - combining social inclusion and social equality? Ch. 8 in C. H. Jørgensen, O. J. Olsen, \& D. Persson Thunqvist (Eds.), Vocational education in the Nordic countries: learning from diversity, Abingdon: Routledge (in press)

Jørgensen, C. H., Järvinen, T., \& Lundahl, L. (2019). A Nordic transition regime? Policies for school-to-work transitions in Sweden, Denmark and Finland. European Educational Research Journal.

Kenworthy, L. 2004. Egalitarian Capitalism, New York, Russell Sage Foundation

Lappalainen, S., Nylund, M., \& Rosvall, P.-Å. (2019). Imagining societies through discourses on educational equality: A cross-cultural analysis of Finnish and Swedish upper secondary curricula from 1970 to the 2010s. European Educational Research Journal.

Lingard, B., Sellar, S. \& Savage, G. 2014. Re-articulating social justice as equity in schooling policy: The effects of testing and data infrastructures. British Journal of Sociology of Education, 35(5), 710-30.

Marsh, J. 2011. Class Dismissed, Month Review Press

Martin, R., Morrison, P. S. (Eds) 2003. Geographies of Labour Market inequality, London, Routledge

Miliband, R. 1973. The State in Capitalist Societies, New York, Basic Books

Miliband, R. 1983. Class Power and State Power, London, Verso

Nylund, M., \& Virolainen, M. (2019). Balancing 'flexibility' and 'employability': The changing role of general studies in the Finnish and Swedish VET curricula of the 1990s and 2010s. European Educational Research Journal.

Persson Thunqvist, D., Hagen Tønder, A., \& Reegård, K. (2019). A tale of two reforms: Institutional change in vocational education and training in Norway and Sweden in the 1990s. European Educational Research Journal, 1474904118823104. 
Piketty, T. 2014. Capital in the Twenty-First Century. Cambridge MA: Belknap.

Standing, G. 2014. A precariat charter, London, Bloomsbury

Thelen, H. 2004. How Institutions evolve, Cambridge, Cambridge University Press

Thelen, K. and Busemeyer, M. 2011. Institutional change in German vocational training: from collectivism toward segmentalism, in M. Busemeyer and C. Trampusch (eds) The political economy of collective skill formation, Cambridge, Cambridge University Press, 68-100

Vaughan-Whitehead, D. (ed) 2016. Europe's Disappearing Middle Class? Evidence from the World of Work, ILO, Geneva, Cheltenham, Edward Elgar

Walther A. 2006. Regimes of youth transitions Choice, flexibility and security in young people's experiences across different European contexts, Nordic Journal of Youth Research, 14(2): 119-139

Wheelahan, L. 2010. Why Knowledge Matters in Curriculum. A social realist argument. London: Routledge

Young, M. \& Lambert, D. (eds) 2014. Knowledge and the Future School: Curriculum and Social Justice. London: Bloomsbury. 